\title{
Kekurangan energi makanan tidak berefek negatif terhadap pertambahan tinggi badan laki-laki usia 18-21 tahun: Studi di Akademi Angkatan Laut Surabaya
}

\section{Lacking of food nutrition did not cause negative effect to men's aged 18-21 years height growth: study in Surabaya naval academy}

\author{
Mega I. D. Ayu dan Myrtati D. Artaria
}

\author{
Departemen Antropologi, Universitas Airlangga, Surabaya \\ Korespondensi: Jalan Airlangga 4-6 Surabaya 60286, Indonesia \\ Phone: +62(31) 5011744 \\ E-mail: myrtati.artaria@ fisip.unair.ac.id
}

\begin{abstract}
This research was carried out to know increase of growth of males attending Indonesian Naval Academy in order to found the normal growth of healthy males for reference of Indonesia population, especially those in 18 to 21 years age. The variables measured were body height, weight, grip strength, and subscapular, biceps, triceps, and suprailiac skinfold thicknesses, while undergoing the first year of training. This research also analysed the difference between more activities and less activities group, while they were given the same kind and amount of food every day. The sample consisted of 50 male cadets aged 18-21 years. The sample was divided into two groups. Group 1: the group that was enrolled in CC (Cross Country) extra-curricular activity, and Group 2: the group that did not enrol in CC (Cross Country) extra-curricular activity. The two groups experienced the same treatment of basic physical exercises, and both received the same quality and amount of food every day. The Group 1 was arranged to get several additional hours of training in the morning and in the afternoon, related to the CC activities. The individuals within the two groups were measured twice-at the beginning of their training year, and a year later. Paired Sample T Test was used in seeing the difference between the two measurements. This research revealed that the physical exercise that was carried out in the Naval academy for a year did not cause any significant increases in the right and left grip strength of both groups. Both of the groups had a high intensity of physical exercise, consequently the significant declined in skinfold thicknesses. A difference in the increase of weight after a year was found between the two groups. The unsignificant increase of weight was found in Group 1. This was caused by the fact that they were subjected to extra physical training compared to Group 2. Although individuals in Group 1 were having tougher training, evidently they experienced significant increase in body height. Moreover, Group 1 experienced that significant increase in body height even though they did not experience significant increases in body weight. The increase of body height in the two groups possibly was caused by the fact that they were still at the age of growth in length. It might as well caused by good nutritive supplies throughout the year, and regular workouts. A further study comparing the cadets with common people must be carried out to further understand the influence of physical exercise and nutritive supplies to the increase of body height among males within the range of this age group.
\end{abstract}

Keywords: anthropometry, height, weight, grip strength, skinfold thickness

Abstrak
Penelitian ini dilakukan untuk mengetahui seberapa besar pertumbuhan pada kadet yang terdaftar di Akademi
Angkatan Laut. Hal ini dilakukan untuk mengetahui angka normal pada laki-laki sehat, untuk menjadi referensi
bagi masyarakat Indonesia, khususnya laki-laki usia 18-21 di area Indonesia. Ukuran-ukuran antropometris yang
diukur adalah berat badan, tinggi badan, kekuatan genggam, tebal lemak, antara dua kelompok yang melakukan
ekstra kurikuler cross country, dan kelompok yang tidak melakukan; sementara mereka diberi makanan dengan
jumlah dan jenis yang sama. Cross-country (Yanus CC) adalah ekstra kurikuler yang paling berat yang
disediakan di akademi ini. Penelitian dilakukan pada tahun pertama mereka masuk akademi. Jumlah sampel
adalah 50 orang kadet usia 18-21 tahun. Paired Sampel T Test digunakan untuk mengetahui perbedaan antara
yang melakukan kegiatan cross-country (Yanus CC) dengan yang tidak. Hasil dari penelitian ini mengungkap
bahwa kegiatan fisik yang dilakukan oleh para kadet ini tidak meningkatkan kekuatan genggam, tapi ada
perubahan setelah setahun dalam hal ketebalan lemak. Namun, terdapat perbedaan signifikan berupa 
pertambahan berat badan, meskipun dari sisi ketebalan lemak telah berkurang. Artinya terdapat pertambahan massa tulang dan massa otot. Meskipun demikian, kelompok pertama yang melakukan kegiatan cross-country, tidak mengalami pertambahan badan yang signifikan, meskipun pertambahan tingginya signifikan. Akibatnya, secara umum mereka terlihat lebih kurus dari pada kelompok yang ke dua. Hal ini penting diketahui oleh masyarakat yang anaknya masih dalam tahap tumbuh kembang, bahwa kegiatan yang banyak, harus diimbangi dengan pasokan makanan yang cukup pula.

Kata-kata kunci: antropometri, tinggi badan, berat badan, kekuatan genggam, ketebalan lemak

\section{Pendahuluan}

Dalam memperhatikan kesehatan masyarakat Indonesia, pemerintah juga perlu memperhatikan kesehatan para Tentara Nasional Indonesia (TNI) sebagai prajurit pembela bangsa. Pekerjaan berat yang dijalani membutuhkan stamina yang tangguh dengan kalori yang cukup agar mampu menjalankan tugas membela Negara dengan sebaik mungkin.

Kadet dengan intensitas latihan fisik menggunakan beban ringan yang teratur dapat menyebabkan perubahan bentuk badan dari yang semula kurus dapat menjadi lebih berisi. Olahragawan yang menginginkan pembentukan otot, latihan fisik yang dilakukan dapat menggunakan beban yang lebih berat agar proses pembentukan otot dapat maksimal, tentunya diimbangi pula dengan pola makan yang memiliki standar gizi yang cukup (Sajoto 1995:3). Penilaian status gizi dibagi menjadi dua, yaitu (1) Penilaian status gizi secara tidak langsung, diantaranya adalah statistik vital, faktor ekologi dan survei konsumsi makanan. (2) penilaian status gizi secara langsung, di antaranya adalah biokimia, biofisik, klinis, dan antropometri (Supariasa 2002:18-21).

Antopometri merupakan salah satu metode yang digunakan dalam penilaian status gizi. Ada dua jenis pengukuran antopometri, yaitu (1) linear, ukuran antropometri yang berhubungan dengan panjang dan berfungsi untuk menunjukkan keadaan gizi kurang akibat kekurangan protein dan gizi di waktu yang telah lalu. Tinggi badan, lingkar dada dan lingkar kepala adalah beberapa contoh variabel pengukuran yang biasa digunakan pada metode linear, dan (2) massa jaringan, ukuran antropometri yang berhubungan dengan massa tubuh dan berfungsi untuk menunjukkan keadaan gizi kurang akibat kekurangan protein dan energi di masa sekarang. Berat badan, lingkar lengan atas dan tebal lemak bawah kulit adalah contoh variabel pengukuran yang digunakan dalam metode massa jaringan (Buku Praktis Ahli Gizi 2005:80-81).

Para kadet mengalami masa peralihan dari masa remaja ke masa dewasa yang ditandai dengan perubahan fisik, fisiologis dan psikososial. Penelitian difokuskan pada status gizi dan latihan fisik sehari-hari para kadet AAL, yang bertujuan untuk mengetahui perubahan antropometri seperti tinggi badan, berat badan, kekuatan genggam tangan kanan dan kiri, serta tebal lemak bawah kulit.

Dalam masa pelatihan, para kadet menjalani latihan ektrakurikuler (disebut Yanus). Yanus cross country (CC) merupakan Yanus terberat di antara Yanus lain yang ada di AAL. Untuk dapat masuk / bergabung ke dalam Yanus CC harus melalui proses seleksi yang tidak mudah. Hanya kadet yang memiliki fisik yang kuat dan kemampuan lari yang cepat yang bisa bergabung dalam Yanus CC ini. Menarik untuk mengetahui apakah beratnya kegiatan sehari-hari pada kadet yang mengikuti Yanus ini akan berpengaruh pada ukuran-ukuran antropometris mereka.

Faktor-faktor yang mempengaruhi antropometri pada manusia adalah keadaan kesegaran jasmani, kekuatan otot-otot tubuh, status gizi dan faktor genetik. Biasanya, apabila terdapat peningkatan gizi dan kalori maka akan diikuti pula oleh kenaikan antropometri (Muhilal 1985 dalam Mulyono 2002). Menurut Fox (Sajoto 1995:30), untuk mendapatkan peningkatan kekuatan otot, hal yang paling efektif adalah dengan memberikan latihan beban agar kekuatan otot dapat berkembang optimal.

Dalam penelitian ini akan ditelaah apakah latihan fisik yang dilakukan selama menjalani pendidikan di AAL, khususnya pada kadet yang mengikuti kegiatan Yanus CC, apakah membawa pengaruh 
terhadap pembentukan badan kadet. Dalam penelitian ini akan dilihat perbedaan ukuran-ukuran antropometris dalam selang waktu 1 tahun, dengan membandingkan antara kadet yang mengikuti Yanus CC dan kadet yang tidak mengikuti Yanus CC.

\section{Metode Penelitian}

Kadet yang diteliti adalah yang mengikuti latihan di AAL Bumimoro Surabaya, tempat para kadet AAL menuntut ilmu, yang berumur antara 18-23 tahun. Pemilihan umur tersebut dimaksudkan karena pada usia tersebut, rata-rata pertumbuhan laki-laki masih berjalan. Kadet yang diukur dibagi menjadi dua kelompok, yaitu kadet yang mengikuti Yanus CC (Cross Country) dan kadet yang tidak mengikuti Yanus sama sekali. Juga, pada tiap kadet akan dilihat perbandingan kemampuan fisik mereka ketika baru masuk menjadi kadet dan setelah satu tahun menjadi kadet di AAL.

Variabel yang diteliti pertama adalah tinggi badan, di mana pengukuran dilakukan menggunakan antropometer. Kadet yang diukur dalam posisi lurus, kaki rapat serta tanpa menggunakan alas kaki. Pengukuran berat badan dilakukan pada kadet dengan mengenakan baju ringan dan tanpa menggunakan alas kaki. Pengukuran kekuatan genggam tangan kanan dan kiri menggunakan alat bernama dynamometer. Pengukuran tebal lemak bawah kulit menggunakan alat "skinfold caliper". Cara pengukuran adalah dengan mencubit jaringan kulit dengan dua jari, lalu jaringan di antara jepitan dua jari yang berisi kulit dan lemak di bawah kulit itu diukur menggunakan kaliper. Pengukuran dilakukan pada jaringan lemak di bawah kulit di area triseps, biseps, subscapula dan supra illiaka, kemudian hasil pengukuran dihitung persentasenya.

$$
\begin{aligned}
& \text { Lemak badan }(\%)=\frac{(4,95-4,5) \times 100 \%}{\mathrm{D}} \\
& \begin{aligned}
\text { Dimana } \mathrm{D} & =1,1581-0,0720 \log \mathrm{E} \\
\text { Keterangan : } \mathrm{D} & =\text { Densitas lemak } \\
\mathrm{E} & =\text { Jumlah pengukuran tebal lemak bawah kulit pada } 4 \text { bagian } \\
& \text { tubuh (trisep, bisep, sub scapula, supra illiaka) }
\end{aligned}
\end{aligned}
$$

Menurut Arikunto (1988), apabila jumlah populasi lebih dari 100 maka jumlah sampel yang diambil bisa antara $10 \%$ hingga $15 \%$, 20\% sampai $25 \%$ atau lebih, sesuai dengan homogenitas populasi. Berdasarkan ini maka peneliti mengambil sampel 50 orang dari jumlah keseluruhan kadet yang ada sekarang yaitu sebanyak 481 orang. Sampel yang digunakan dalam penelitian ini adalah kadet AAL yang mengikuti Yanus CC (Cross Country) sebanyak 25 orang dan kadet yang tidak mengikuti Yanus sebanyak 25 orang juga.

Data dianalisis dengan menggunakan SPSS 10. Metode parametrik digunakan setelah diketahui bahwa data berdistribusi normal. Dalam penelitian pada Kadet Akademi Angkatan Laut (AAL), peneliti membandingkan dua pengukuran pada subjek yang sama terhadap pengaruh maupun perlakuan tertentu. Kemudian atas dasar tersebut di atas, maka peneliti menggunakan Paired-Sample $\mathrm{T}$ tes atau yang lebih dikenal dengan dengan pre-post design. Untuk uji hipotesis, aturan yang digunakan adalah:

Jika Sig $>\alpha$, maka Ho diterima

Jika Sig $<\alpha$, maka Ho ditolak

Dimana $\alpha$ adalah 0,025 (Trihendradi 2005).

\section{Hasil dan Pembahasan}

Standar porsi yang dibutuhkan pada menu setiap kali makan di AAL Surabaya adalah untuk beras setiap orang 250 gram (siang) 150 gram (malam) 200 gram (pagi), ayam 145 gram, daging 80 gram, ikan 125 gram, tahu 60 gram, tempe 50 gram, buah 250 gram untuk semangka dan melon, buah 
lainnya 150 gram, sayuran 150-250 gram. Hal ini disesuaikan dengan kebutuhan energi setiap orang yaitu 4000-4500 kalori. Menu makanan kadet memiliki variasi setiap harinya selama dua minggu dan akan berulang selama dua minggu berikutnya.

Untuk dapat mendukung setiap kegiatan, masing-masing pribadi harus menjaga kesehatan sebaikbaiknya dan membiasakan diri menilai dan mengawasi kesehatannya. Jika dilihat berdasarkan Muhilal dkk. (1996) maka kegiatan kadet masuk ke dalam kategori kegiatan sedang mendekati berat.

Rata-rata usia kadet yang mengikuti Yanus CC sebelum dimulai latihan di AAL adalah 18 tahun. Tinggi badan rata-rata mereka adalah $170,76 \mathrm{~cm}$. Berat badan kadet pada kelompok ini dapat diketahui pada Tabel 1. Keberagaman berat badan dijumpai, meskipun tinggi badannya cukup seragam. Berat badan berkisar antara $52-78 \mathrm{~kg}$, dengan rata-rata $64 \mathrm{~kg}$. Selang satu tahun kemudian, rata-rata tinggi badan naik menjadi $171,22 \mathrm{~cm}$, dan rata-rata berat badan naik menjadi $65 \mathrm{~kg}$ (Tabel 1).

Tabel 1.

Usia, tinggi dan berat badan kadet yang mengikuti Yanus CC sebelum dan sesudah masuk AAL

\begin{tabular}{ccccccc}
\hline Kadet \# & \multicolumn{2}{c}{ Umur (tahun) } & \multicolumn{2}{c}{ Tinggi Badan $(\mathbf{c m})$} & \multicolumn{2}{c}{ Berat Badan $(\mathbf{k g})$} \\
& Sebelum & Sesudah & Sebelum & Sesudah & Sebelum & Sesudah \\
\hline 1 & 18 & 19 & 172 & 173 & 64 & 63 \\
2 & 18 & 19 & 173 & 174 & 57 & 55 \\
3 & 18 & 19 & 175 & 177,5 & 71 & 72 \\
4 & 18 & 19 & 175 & 175 & 78 & 75 \\
5 & 18 & 19 & 174 & 175 & 64 & 63 \\
6 & 18 & 19 & 171 & 172 & 70 & 72 \\
7 & 18 & 19 & 177 & 179 & 76 & 74 \\
8 & 18 & 19 & 174 & 177 & 62 & 64 \\
9 & 18 & 19 & 177 & 177 & 75 & 71 \\
10 & 18 & 19 & 171 & 171 & 65 & 78 \\
11 & 18 & 19 & 172 & 172 & 64 & 65 \\
12 & 18 & 19 & 168 & 168,5 & 65 & 65 \\
13 & 18 & 19 & 169 & 169 & 59 & 60 \\
14 & 18 & 19 & 166 & 167 & 58 & 57 \\
15 & 18 & 19 & 171 & 171 & 68 & 70 \\
16 & 18 & 19 & 168 & 168 & 65 & 63 \\
17 & 18 & 19 & 172 & 172 & 61 & 60 \\
18 & 18 & 19 & 163 & 167 & 60 & 62 \\
19 & 18 & 19 & 173 & 173 & 68 & 72 \\
20 & 18 & 19 & 163 & 167 & 52 & 55 \\
21 & 18 & 19 & 168 & 168,5 & 56 & 54 \\
22 & 18 & 19 & 165 & 166 & 53 & 59 \\
23 & 18 & 19 & 170 & 173 & 70 & 67 \\
24 & 18 & 19 & 167 & 168 & 65 & 68 \\
25 & 18 & 19 & 167 & 168 & 63 & 60 \\
\hline Rata-rata & $\mathbf{1 8}$ & $\mathbf{1 9}$ & $\mathbf{1 7 0 , 7 6}$ & $\mathbf{1 7 1 , 2 2}$ & $\mathbf{6 4}$ & $\mathbf{6 5}$ \\
\hline
\end{tabular}

Hasil uji kekuatan genggam tangan kadet yang mengikuti Yanus CC, pada tangan kanan sebelum masuk AAL rata-rata sebesar $42 \mathrm{~kg}$, dan rata-rata $38 \mathrm{~kg}$ pada tangan kiri (Tabel 2). Setelah satu tahun, kekuatan genggam rata-rata pada tangan kanan adalah $42 \mathrm{Kg}$, dan tangan kiri rata-rata $37 \mathrm{Kg}$. 
Tabel 2.

Kekuatan genggam tangan kanan dan kiri Kadet yang mengikuti Yanus CC sebelum dan sesudah masuk AAL

\begin{tabular}{ccccccc}
\hline Kadet \# & \multicolumn{2}{c}{ Umur (tahun) } & \multicolumn{2}{c}{ Kanan (Kg) } & \multicolumn{2}{c}{ Kiri (Kg) } \\
& Sebelum & Sesudah & Sebelum & Sesudah & Sebelum & Sesudah \\
\hline 1 & 18 & 19 & 43 & 45 & 36 & 38 \\
2 & 18 & 19 & 41 & 43 & 39 & 39 \\
3 & 18 & 19 & 44 & 37 & 42 & 35 \\
4 & 18 & 19 & 44 & 36 & 43 & 35 \\
5 & 18 & 19 & 43 & 51 & 39 & 40 \\
6 & 18 & 19 & 36 & 44 & 31 & 34 \\
7 & 18 & 19 & 38 & 49 & 44 & 43 \\
8 & 18 & 19 & 35 & 40 & 32 & 34 \\
9 & 18 & 19 & 51 & 48 & 44 & 44 \\
10 & 18 & 19 & 37 & 51 & 31 & 40 \\
11 & 18 & 19 & 49 & 53 & 40 & 39 \\
12 & 18 & 19 & 40 & 49 & 36 & 38 \\
13 & 18 & 19 & 38 & 29 & 35 & 33 \\
14 & 18 & 19 & 38 & 45 & 33 & 37 \\
15 & 18 & 19 & 40 & 37 & 40 & 37 \\
16 & 18 & 19 & 52 & 44 & 50 & 39 \\
17 & 18 & 19 & 39 & 45 & 38 & 42 \\
18 & 18 & 19 & 37 & 40 & 33 & 30 \\
19 & 18 & 19 & 51 & 44 & 38 & 40 \\
20 & 18 & 19 & 39 & 41 & 32 & 42 \\
21 & 18 & 19 & 41 & 46 & 39 & 35 \\
22 & 18 & 19 & 49 & 52 & 40 & 35 \\
23 & 18 & 19 & 49 & 39 & 39 & 46 \\
24 & 18 & 19 & 35 & 45 & 35 & 38 \\
25 & 18 & 19 & 38 & 50 & 39 & 38 \\
Rata-rata & $\mathbf{1 8}$ & $\mathbf{1 9}$ & $\mathbf{4 2}$ & $\mathbf{4 2}$ & $\mathbf{3 8}$ & $\mathbf{3 7}$ \\
\hline & & & & & &
\end{tabular}

Kelompok kadet yang mengikuti Yanus CC mempunyai tebal lemak bawah kulit rata-rata sebesar $11 \%$, sebelum dimulainya latihan di AAL. Tebal lemak bawah kulit tertinggi adalah sebesar 15,05\% dan tebal lemak bawah kulit terendah adalah sebesar $8,41 \%$. Setelah selang satu tahun, tebal lemak rata-rata adalah $0,41 \%$ (Tabel 3). 
Tabel 3.

Tebal lemak bawah kulit kadet yang mengikuti Yanus CC sebelum dan sesudah masuk AAL

\begin{tabular}{ccccc}
\hline Kadet \# & \multicolumn{2}{c}{ Umur (tahun) } & \multicolumn{2}{c}{ Tebal Lemak (\%) } \\
& Sebelum & Sesudah & Sebelum & Sesudah \\
\hline 1 & 18 & 19 & 9,83 & 0,41 \\
2 & 18 & 19 & 9,31 & 0,41 \\
3 & 18 & 19 & 10,68 & 0,42 \\
4 & 18 & 19 & 14,78 & 0,42 \\
5 & 18 & 19 & 10,06 & 0,41 \\
6 & 18 & 19 & 14,09 & 0,41 \\
7 & 18 & 19 & 9,95 & 0,41 \\
8 & 18 & 19 & 8,41 & 0,41 \\
9 & 18 & 19 & 15,05 & 0,41 \\
10 & 18 & 19 & 14,63 & 0,41 \\
11 & 18 & 19 & 12,20 & 0,41 \\
12 & 18 & 19 & 13,03 & 0,41 \\
13 & 18 & 19 & 9,72 & 0,41 \\
14 & 18 & 19 & 11,38 & 0,41 \\
15 & 18 & 19 & 13,83 & 0,42 \\
16 & 18 & 19 & 10,14 & 0,40 \\
17 & 18 & 19 & 9,80 & 0,41 \\
18 & 18 & 19 & 11,97 & 0,41 \\
19 & 18 & 19 & 12,72 & 0,41 \\
20 & 18 & 19 & 12,92 & 0,42 \\
21 & 18 & 19 & 10,47 & 0,41 \\
22 & 18 & 19 & 9,57 & 0,41 \\
23 & 18 & 19 & 8,72 & 0,41 \\
24 & 18 & 19 & 12,24 & 0,41 \\
25 & 18 & 19 & 10,09 & 0,41 \\
Rata-rata & $\mathbf{1 8}$ & $\mathbf{1 9}$ & $\mathbf{1 1}$ & $\mathbf{0 , 4 1}$ \\
\hline & & & & \\
\hline
\end{tabular}

Sebelum dimulai latihan di AAL, rata-rata tinggi badan kadet pada kelompok yang tidak mengikuti Yanus adalah 169,4 cm, sementara berat badan mereka rata-rata $62 \mathrm{~kg}$. Selang satu tahun kemudian, rata-rata tinggi badan sedikit naik, yaitu $169,98 \mathrm{~cm}$, dan berat badan mereka mempunyai rata-rata tetap seperti setahun sebelumnya yaitu $62 \mathrm{~kg}$ (Tabel 4). 
Tabel 4.

Usia, tinggi dan berat badan kadet yang tidak mengikuti Yanus sebelum dan sesudah masuk AAL

\begin{tabular}{ccccccc}
\hline Kadet \# & \multicolumn{2}{c}{ Umur (tahun) } & \multicolumn{2}{c}{ Tinggi Badan $(\mathbf{c m})$} & \multicolumn{2}{c}{ Berat Badan $(\mathbf{k g})$} \\
& Sebelum & Sesudah & Sebelum & Sesudah & Sebelum & Sesudah \\
\hline 26 & 19 & 20 & 164 & 166 & 64,5 & 64 \\
27 & 18 & 19 & 171 & 172 & 60 & 60 \\
28 & 19 & 20 & 175 & 176,5 & 69 & 75 \\
29 & 18 & 19 & 172 & 173 & 65 & 65 \\
30 & 18 & 19 & 168 & 170 & 65 & 65 \\
31 & 19 & 20 & 168 & 170 & 68 & 65 \\
32 & 19 & 20 & 166 & 167 & 60 & 61 \\
33 & 19 & 20 & 173 & 174 & 61 & 63 \\
34 & 18 & 19 & 168 & 169 & 58 & 59 \\
35 & 19 & 20 & 170 & 170 & 64 & 65 \\
36 & 18 & 19 & 170 & 166 & 58 & 58 \\
37 & 19 & 20 & 176 & 177 & 70 & 70 \\
38 & 20 & 21 & 164 & 166 & 63 & 65 \\
39 & 19 & 20 & 173 & 172 & 56 & 59 \\
40 & 18 & 19 & 168 & 166 & 66 & 60 \\
41 & 18 & 19 & 168 & 168 & 57 & 58 \\
42 & 18 & 19 & 167 & 168 & 62 & 63 \\
43 & 18 & 19 & 171 & 168 & 60 & 61 \\
44 & 18 & 19 & 171 & 172 & 64 & 59 \\
45 & 19 & 20 & 170 & 171,5 & 59 & 64 \\
46 & 18 & 19 & 173 & 172 & 59 & 61 \\
47 & 18 & 19 & 164 & 165 & 61 & 62 \\
48 & 18 & 19 & 174 & 174 & 57 & 59 \\
49 & 19 & 20 & 164 & 164,5 & 57 & 55 \\
50 & 19 & 20 & 171 & 172 & 64 & 70 \\
Rata-rata & $\mathbf{1 8}$ & $\mathbf{1 9}$ & $\mathbf{1 6 9 , 4}$ & $\mathbf{1 6 9 , 9 8}$ & $\mathbf{6 2}$ & $\mathbf{6 2}$ \\
\hline
\end{tabular}

Kekuatan genggam tangan kanan dan tangan kiri pada kelompok kadet yang tidak mengikuti Yanus CC sebelum menjalani pendidikan di AAL, tangan kanan umumnya memiliki kekuatan lebih besar daripada tangan kiri. Kadet kelompok ini memiliki rata-rata kekuatan genggam adalah sebesar $41 \mathrm{~kg}$, ada 10 orang yang memiliki kekuatan di bawah $41 \mathrm{~kg}$. Untuk kekuatan genggam tertinggi adalah 59 $\mathrm{kg}$ dan kekuatan genggam terendah adalah $28 \mathrm{~kg}$, sedangkan untuk kekuatan genggam tangan kiri pada kadet kelompok ini memiliki rata-rata $40 \mathrm{~kg}$. Kekuatan genggam tertinggi pada tangan kiri adalah $53 \mathrm{~kg}$ dan kekuatan genggam terendah adalah $27 \mathrm{~kg}$. 
Tabel 5.

Kekuatan genggam tangan kanan dan kiri kadet yang tidak mengikuti Yanus CC sebelum dan sesudah masuk AAL

\begin{tabular}{ccccccc}
\hline Kadet \# & \multicolumn{2}{c}{ Umur (tahun) } & \multicolumn{2}{c}{ Kanan (Kg) } & \multicolumn{2}{c}{ Kiri (Kg) } \\
& Sebelum & Sesudah & Sebelum & Sesudah & Sebelum & Sesudah \\
\hline 26 & 19 & 20 & 36 & 37 & 31 & 27 \\
27 & 18 & 19 & 39 & 37 & 35 & 36 \\
28 & 19 & 20 & 43 & 51 & 37 & 35 \\
29 & 18 & 19 & 43 & 40 & 36 & 39 \\
30 & 18 & 19 & 39 & 40 & 39 & 43 \\
31 & 19 & 20 & 48 & 44 & 50 & 41 \\
32 & 19 & 20 & 40 & 42 & 39 & 32 \\
33 & 19 & 20 & 44 & 44 & 47 & 40 \\
34 & 18 & 19 & 39 & 26 & 36 & 29 \\
35 & 19 & 20 & 36 & 47 & 39 & 43 \\
36 & 18 & 19 & 42 & 42 & 42 & 33 \\
37 & 19 & 20 & 48 & 45 & 53 & 48 \\
38 & 20 & 21 & 42 & 41 & 36 & 38 \\
39 & 19 & 20 & 38 & 32 & 35 & 32 \\
40 & 18 & 19 & 43 & 47 & 38 & 46 \\
41 & 18 & 19 & 31 & 43 & 40 & 37 \\
42 & 18 & 19 & 43 & 29 & 41 & 29 \\
43 & 18 & 19 & 47 & 51 & 40 & 44 \\
44 & 18 & 19 & 43 & 43 & 44 & 39 \\
45 & 19 & 20 & 47 & 48 & 53 & 36 \\
46 & 18 & 19 & 43 & 37 & 42 & 41 \\
47 & 18 & 19 & 37 & 39 & 40 & 37 \\
48 & 18 & 19 & 43 & 42 & 42 & 39 \\
49 & 19 & 20 & 28 & 35 & 27 & 25 \\
50 & 19 & 20 & 44 & 42 & 44 & 32 \\
Rata-rata & $\mathbf{1 8}$ & $\mathbf{1 9}$ & $\mathbf{4 1}$ & $\mathbf{4 2}$ & $\mathbf{4 0}$ & $\mathbf{3 7}$ \\
\hline & & & & & &
\end{tabular}

Tebal lemak bawah kulit rata-rata kadet adalah $11 \%$. Ada 10 kadet yang memiliki tebal lemak bawah kulit di bawah $11 \%$. Untuk tebal lemak bawah kulit tertinggi adalah $14,17 \%$ dan tebal lemak bawah kulit terendah pada kadet kelompok ini adalah 8,49\%. 
Tabel 6.

Tebal lemak bawah kulit kadet yang tidak mengikuti Yanus sebelum dan sesudah masuk AAL

\begin{tabular}{|c|c|c|c|c|}
\hline \multirow[t]{2}{*}{ Kadet \# } & \multicolumn{2}{|c|}{ Umur (tahun) } & \multicolumn{2}{|c|}{ Tebal Lemak } \\
\hline & Sebelum & Sesudah & Sebelum & Sesudah \\
\hline 26 & 19 & 20 & 12,82 & 0,42 \\
\hline 27 & 18 & 19 & 10,54 & 0,41 \\
\hline 28 & 19 & 20 & 13,67 & 0,42 \\
\hline 29 & 18 & 19 & 11,67 & 0,41 \\
\hline 30 & 18 & 19 & 10,52 & 0,41 \\
\hline 31 & 19 & 20 & 11,25 & 0,41 \\
\hline 32 & 19 & 20 & 11,59 & 0,41 \\
\hline 33 & 19 & 20 & 8,49 & 0,41 \\
\hline 34 & 18 & 19 & 9,64 & 0,41 \\
\hline 35 & 19 & 20 & 13,56 & 0,42 \\
\hline 36 & 18 & 19 & 10,96 & 0,41 \\
\hline 37 & 19 & 20 & 11,89 & 0,41 \\
\hline 38 & 20 & 21 & 13,25 & 0,42 \\
\hline 39 & 19 & 20 & 10,09 & 0,41 \\
\hline 40 & 18 & 19 & 9,27 & 0,41 \\
\hline 41 & 18 & 19 & 11,59 & 0,42 \\
\hline 42 & 18 & 19 & 11,47 & 0,41 \\
\hline 43 & 18 & 19 & 11,36 & 0,42 \\
\hline 44 & 18 & 19 & 12,5 & 0,41 \\
\hline 45 & 19 & 20 & 9,99 & 0,41 \\
\hline 46 & 18 & 19 & 8,64 & 0,41 \\
\hline 47 & 18 & 19 & 12,66 & 0,42 \\
\hline 48 & 18 & 19 & 10,47 & 0,41 \\
\hline 49 & 19 & 20 & 12,77 & 0,42 \\
\hline 50 & 19 & 20 & 14,17 & 0,41 \\
\hline Rata-rata & 18 & 19 & 11 & $\mathbf{0 , 4 1}$ \\
\hline
\end{tabular}

Kadet yang mengikuti Yanus CC setelah masuk AAL mempunyai tinggi badan tertinggi $179 \mathrm{~cm}$ dan tinggi badan terendah adalah $163 \mathrm{~cm}$, dengan rata-rata 171,22 cm. Kadet pada kelompok ini memiliki berat-badan rata-rata $65 \mathrm{~kg}$. Berat badan tertinggi adalah $78 \mathrm{~kg}$ dan untuk berat badan terendah adalah $54 \mathrm{~kg}$.

Kekuatan genggam tangan kanan kadet rata-rata adalah $44 \mathrm{~kg}$, hanya 9 orang yang memiliki kekuatan genggam tangan di bawah $44 \mathrm{~kg}$. Untuk kekuatan genggam tangan tertinggi adalah sebesar $53 \mathrm{~kg}$ dan terendah adalah sebesar $29 \mathrm{~kg}$, sedangkan tangan kiri kadet memiliki kekuatan genggam tangan ratarata sebesar $38 \mathrm{~kg}$. Hanya terdapat 10 orang yang memiliki kekuatan genggam tangan kiri di bawah $38 \mathrm{~kg}$. Untuk kekuatan genggam tangan kiri tertinggi adalah sebesar $46 \mathrm{~kg}$ dan kekuatan genggam tangan kiri terendah adalah $30 \mathrm{~kg}$.

Kelompok kadet yang mengikuti Yanus CC, setelah satu tahun menjalani pendidikan di AAL memiliki tebal lemak bawah kulit rata-rata adalah 0,41\%. Hanya ada 1 kadet yang memiliki tebal lemak bawah kulit di bawah 0,41\%. Tebal lemak bawah kulit tertinggi pada kelompok kadet yang mengikuti Yanus CC adalah sebesar 0,42 \% sedangkan untuk tebal lemak bawah kulit kadet terendah pada kelompok ini adalah sebesar $0,40 \%$.

Kadet pada kelompok ini memiliki rata-rata tinggi badan $169,98 \mathrm{~cm}$, di antaranya 10 orang memiliki tinggi badan dibawah $169,98 \mathrm{~cm}$. Tinggi badan tertinggi adalah $177 \mathrm{~cm}$ dan tinggi badan terendah adalah 164,5 cm. Kadet pada kelompok ini memiliki rata-rata berat badan $62 \mathrm{~kg}$, hanya 5 orang yang memiliki berat badan di bawah $62 \mathrm{~kg}$. Berat badan tertinggi kadet pada kelompok ini adalah $75 \mathrm{~kg}$ dan berat badan terendah adalah $55 \mathrm{~kg}$. 
Kekuatan genggam tangan kanan kadet rata-rata adalah $42 \mathrm{~kg}$ dan kekuatan genggam tangan kiri kadet rata-rata adalah $37 \mathrm{~kg}$. Pada tangan kanan, kekuatan genggam tangan kadet yang tertinggi adalah sebesar $65 \mathrm{~kg}$ dan kekuatan genggam tangan terendah adalah sebesar $26 \mathrm{~kg}$, sedangkan pada tangan kiri, kekuatan genggam tangan kadet yang tertinggi adalah sebesar $48 \mathrm{~kg}$ dan kekuatan genggam tangan kadet terendah adalah sebesar $25 \mathrm{~kg}$.

Hasil pengukuran tebal lemak bawah kulit kadet setelah menjalani pendidikan di AAL pada kelompok kadet yang tidak mengikuti Yanus CC adalah sebagai berikut, tebal lemak bawah kulit rata-rata kadet adalah sebesar $0,41 \%$. Terdapat 8 orang kadet yang memiliki tebal lemak bawah kulit di atas rata-rata pada kelompok kadet yang tidak mengikuti Yanus, yaitu sebesar 0,42\%.

Tabel 7.

Uji hipotesis tinggi badan kadet

\begin{tabular}{|c|c|c|c|c|}
\hline \multirow[t]{2}{*}{ Kadet } & \multicolumn{2}{|c|}{$\begin{array}{c}\text { Kadet yang mengikuti Yanus CC } \\
\text { (Cross Country) }\end{array}$} & \multicolumn{2}{|c|}{ Kadet yang tidak mengikuti Yanus } \\
\hline & $\begin{array}{l}\text { Tinggi Badan } \\
\text { Sebelum }\end{array}$ & $\begin{array}{l}\text { Tinggi Badan } \\
\text { Sesudah }\end{array}$ & $\begin{array}{l}\text { Tinggi Badan } \\
\text { Sebelum }\end{array}$ & $\begin{array}{l}\text { Tinggi Badan } \\
\text { Sesudah }\end{array}$ \\
\hline $\mathbf{n}$ & 25 & 25 & 25 & 25 \\
\hline Minimum & 163 & 166 & 164 & 165 \\
\hline Maximum & 177 & 179 & 176 & 177 \\
\hline Mean & 170,44 & 171,54 & 169,12 & 170,42 \\
\hline Sd & 3,97 & 3,78 & 3,55 & 3,36 \\
\hline Correlation & \multicolumn{2}{|c|}{0,948} & \multicolumn{2}{|c|}{0,968} \\
\hline Sig & \multicolumn{2}{|c|}{0,000} & \multicolumn{2}{|c|}{0,000} \\
\hline Sig (2-tailed) & \multicolumn{2}{|c|}{0,000} & \multicolumn{2}{|c|}{0,000} \\
\hline
\end{tabular}

Tabel 8.

Uji hipotesis berat badan kadet

\begin{tabular}{|c|c|c|c|c|}
\hline \multirow[t]{2}{*}{ Kadet } & \multicolumn{2}{|c|}{$\begin{array}{c}\text { Kadet yang mengikuti Yanus CC } \\
\text { (Cross Country) }\end{array}$} & \multicolumn{2}{|c|}{ Kadet yang tidak mengikuti Yanus } \\
\hline & $\begin{array}{l}\text { Berat Badan } \\
\text { Sebelum }\end{array}$ & $\begin{array}{l}\text { Berat Badan } \\
\text { Sesudah }\end{array}$ & $\begin{array}{l}\text { Berat Badan } \\
\text { Sebelum }\end{array}$ & $\begin{array}{l}\text { Berat Badan } \\
\text { Sesudah }\end{array}$ \\
\hline $\mathbf{n}$ & 25 & 25 & 25 & 25 \\
\hline Minimum & 52 & 54 & 56 & 55 \\
\hline Maximum & 78 & 78 & 70 & 75 \\
\hline Mean & 64,36 & 64,96 & 61,46 & 62,64 \\
\hline Sd & 6,72 & 6,74 & 3,79 & 4,42 \\
\hline Correlation & \multicolumn{2}{|c|}{0,856} & \multicolumn{2}{|c|}{0,848} \\
\hline Sig & \multicolumn{2}{|c|}{0,000} & \multicolumn{2}{|c|}{0,000} \\
\hline Sig (2-tailed) & \multicolumn{2}{|c|}{0,414} & \multicolumn{2}{|c|}{0,020} \\
\hline
\end{tabular}


Tabel 9.

Uji hipotesis kekuatan genggam tangan kanan kadet

\begin{tabular}{|c|c|c|c|c|}
\hline \multirow[t]{2}{*}{ Kadet } & \multicolumn{2}{|c|}{$\begin{array}{c}\text { Kadet yang mengikuti Yanus CC } \\
\text { (Cross Country) }\end{array}$} & \multicolumn{2}{|c|}{ Kadet yang tidak mengikuti Yanus } \\
\hline & $\begin{array}{c}\text { Kekuatan } \\
\text { Genggam } \\
\text { Tangan Kanan } \\
\text { Sebelum } \\
\end{array}$ & $\begin{array}{c}\text { Kekuatan } \\
\text { Genggam } \\
\text { Tangan Kanan } \\
\text { Sesudah } \\
\end{array}$ & $\begin{array}{c}\text { Kekuatan } \\
\text { Genggam } \\
\text { Tangan Kanan } \\
\text { Sebelum } \\
\end{array}$ & $\begin{array}{c}\text { Kekuatan } \\
\text { Genggam } \\
\text { Tangan Kanan } \\
\text { Sesudah }\end{array}$ \\
\hline $\mathbf{n}$ & 25 & 25 & 25 & 25 \\
\hline Minimum & 35 & 29 & 28 & 26 \\
\hline Maximum & 52 & 53 & 48 & 51 \\
\hline Mean & 41,88 & 44,12 & 40,92 & 40,96 \\
\hline Sd & 5,38 & 5,80 & 4,91 & 6,15 \\
\hline Correlation & \multicolumn{2}{|c|}{0,167} & \multicolumn{2}{|c|}{0,396} \\
\hline Sig & \multicolumn{2}{|c|}{0,424} & \multicolumn{2}{|c|}{0.050} \\
\hline Sig (2-tailed) & \multicolumn{2}{|c|}{0,134} & \multicolumn{2}{|c|}{0,974} \\
\hline
\end{tabular}

Tabel 10.

Uji hipotesis kekuatan genggam tangan kiri kadet

\begin{tabular}{|c|c|c|c|c|}
\hline \multirow[t]{2}{*}{ Kadet } & \multicolumn{2}{|c|}{$\begin{array}{c}\text { Kadet yang mengikuti Yanus CC } \\
\text { (Cross Country) }\end{array}$} & \multicolumn{2}{|c|}{ Kadet yang tidak mengikuti Yanus } \\
\hline & $\begin{array}{c}\text { Kekuatan } \\
\text { Genggam } \\
\text { Tangan Kiri } \\
\text { Sebelum }\end{array}$ & $\begin{array}{c}\text { Kekuatan } \\
\text { Genggam } \\
\text { Tangan Kiri } \\
\text { Sesudah }\end{array}$ & $\begin{array}{c}\text { Kekuatan } \\
\text { Genggam } \\
\text { Tangan Kiri } \\
\text { Sebelum }\end{array}$ & $\begin{array}{c}\text { Kekuatan } \\
\text { Genggam } \\
\text { Tangan Kiri } \\
\text { Sesudah }\end{array}$ \\
\hline $\mathbf{n}$ & 25 & 25 & 25 & 25 \\
\hline Minimum & 31 & 30 & 27 & 25 \\
\hline Maximum & 50 & 46 & 53 & 48 \\
\hline Mean & 37,92 & 38,04 & 39,32 & 36,84 \\
\hline Sd & 4,65 & 3,71 & 6,66 & 5,93 \\
\hline Correlation & \multicolumn{2}{|c|}{0,306} & \multicolumn{2}{|c|}{0,518} \\
\hline Sig & \multicolumn{2}{|c|}{0,136} & \multicolumn{2}{|c|}{0,008} \\
\hline Sig (2-tailed) & \multicolumn{2}{|c|}{0,905} & \multicolumn{2}{|c|}{0.057} \\
\hline
\end{tabular}

Tabel 11.

Uji hipotesis tebal lemak bawah kulit kadet

\begin{tabular}{|c|c|c|c|c|}
\hline \multirow[t]{2}{*}{ Kadet } & \multicolumn{2}{|c|}{$\begin{array}{l}\text { Kadet yang mengikuti Yanus CC } \\
\text { (Cross Country) }\end{array}$} & \multicolumn{2}{|c|}{ Kadet yang tidak mengikuti Yanus } \\
\hline & $\begin{array}{c}\text { Tebal Lemak } \\
\text { Bawah Kulit } \\
\text { Sebelum }\end{array}$ & $\begin{array}{c}\text { Tebal Lemak } \\
\text { Bawah Kulit } \\
\text { Sesudah }\end{array}$ & $\begin{array}{c}\text { Tebal Lemak } \\
\text { Bawah Kulit } \\
\text { Sebelum }\end{array}$ & $\begin{array}{c}\text { Tebal Lemak } \\
\text { Bawah Kulit } \\
\text { Sesudah }\end{array}$ \\
\hline $\mathbf{n}$ & 25 & 25 & 25 & 25 \\
\hline Minimum & 8,41 & 0,40 & 8,49 & 0,41 \\
\hline Maximum & 15,05 & 0,42 & 14,17 & 0,42 \\
\hline Mean & 11,42 & 0,41 & 11,39 & 0,41 \\
\hline Sd & 2,01 & 4,39 & 1,55 & 4,76 \\
\hline Correlation & \multicolumn{2}{|c|}{0,382} & \multicolumn{2}{|c|}{0,593} \\
\hline Sig & \multicolumn{2}{|c|}{0,050} & \multicolumn{2}{|c|}{0,002} \\
\hline Sig (2-tailed) & \multicolumn{2}{|c|}{0,000} & \multicolumn{2}{|c|}{0,000} \\
\hline
\end{tabular}


Baik pada kelompok kadet yang mengikuti Yanus CC maupun kadet yang tidak mengikuti Yanus sama sekali, signifikansi didapat pada pengukuran tinggi badan dan pengukuran ketebalan lemak tubuh, sedangkan untuk kekuatan otot tangan kanan dan tangan kiri pada dua kelompok ini tidak terdapat signifikansi. Perbedaan tingkat signifikansi hanya terdapat pada pengukuran berat badan kedua kelompok. Pada variabel pengukuran berat badan ini, perubahan secara signifikan terjadi pada kelompok kadet yang tidak mengikuti Yanus. Untuk kelompok kadet yang mengikuti Yanus CC penambahan berat badan tidak signifikan.

Hasil analisis yang menunjukkan bahwa adanya pertambahan tinggi badan yang signifikan pada dua kelompok kadet tersebut sesuai dengan teori yang menunjukkan bahwa, tinggi badan pria masih akan dapat bertambah hingga usia 23 tahun meskipun sangat lambat (Glinka 1987:65), sedangkan Soetjiningsih (1995) mengatakan bahwa tinggi badan pria akan terhenti pada usia 20 tahun namun ruas-ruas tulang belakang masih terus akan tumbuh hingga usia 30 tahun.

Berat badan manusia mengalami fluktuasi wajar setiap harinya bergantung dari keluaran dan masukan yang diperoleh tubuh masing-masing individu (Soetjiningsih 1995), hal ini yang dapat menyebabkan pengukuran berat badan tidak signifikan. Namun berat badan tetap bisa dijaga dalam posisi ideal bila individu tersebut disiplin dalam mengatur pola makan dengan aktifitas yang dilakukannya (Hartono 2000) sehingga pada kelompok kadet yang mengikuti Yanus CC, penambahan berat badannya tidak signifikan. Kelompok kadet yang mengikuti Yanus CC lebih banyak mengalami penurunan berat badan sedangkan pada kelompok kadet yang tidak mengikuti Yanus sama sekali lebih banyak terjadi penambahan berat badan.

Kekuatan otot tangan pada individu dapat mengalami peningkatan apabila dilakukan latihan khusus yang rutin dengan penambahan beban agar dapat merangsang penyesuaian fisiologis dalam tubuh yang mendorong peningkatan kemampuan otot (Sajoto 1995). Meskipun data di lapangan menunjukkan bahwa latihan kadet telah sesuai dengan prinsip overload yang dikemukakan oleh Fox (1981) dalam (Sajoto 1995) namun hasil pengukuran kekuatan genggam tangan kanan dan kiri pada kedua kadet sama-sama diperoleh hasil yang tidak signifikan. Hal ini dapat terjadi karena kadet tidak dalam keadaan tubuh yang prima saat tes berlangsung. Dapat juga disebabkan karena kecilnya jumlah sampel yang dilakukan peneliti khusus pada kekuatan otot tangan kanan dan kiri ini sementara variasinya terlalu besar. Dalam pengukuran kekuatan genggam tangan kanan dan tangan kiri ini menggunakan alat yang sama pada saat pengukuran awal.

Hasil analisis ketebalan lemak tubuh pada kedua kelompok menunjukkan hasil yang signifikan. Lemak dalam tubuh mengalami pembakaran karena tingginya latihan fisik yang dijalani oleh kadet. Meskipun kelompok kadet yang mengikuti Yanus CC mendapatkan porsi yang lebih dalam latihan fisik, namun adanya target kekuatan fisik yang harus meningkat tiap tahun yang direalisasikan dalam ujian Samapta membuat kelompok kadet yang tidak mengikuti Yanus juga harus berlatih dengan keras guna mendapatkan hasil yang maksimal dalam pendidikan di AAL khususnya yang menyangkut fisik.

\section{Simpulan}

Hasil dari penelitian ini mengungkap bahwa latihan fisik yang dilakukan di AAL selama setahun tidak membawa pengaruh secara significant pada penambahan kekuatan genggam tangan kanan dan kiri, di kedua kelompok di atas. Kedua kelompok kadet sama-sama memiliki intensitas latihan fisik yang tinggi, karenanya terjadi penurunan tebal lemak di bawah kulit secara signifikan. Perbedaan antara kedua kelompok hanya terletak pada variabel berat badan. Ketidaksignifikanan pertambahan berat badan terjadi pada kelompok kadet yang mengikuti Yanus CC karena mereka mendapat tambahan waktu latihan. Meskipun ada perbedaan perlakuan dalam beban latihan dalam rentang satu tahun, ternyata kedua kelompok tetap mengalami penambahan tinggi badan secara signifikan. Bahkan, kelompok yang mengikuti Yanus CC mengalami penambahan tinggi badan, meskipun tidak ada penambahan berat badan yang signifikan. Pertambahan tinggi badan pada kedua kelompok mungkin 
disebabkan karena memang pada umur mereka masih dimungkinkan ada pertambahan tinggi badan, atau didorong oleh pasokan gizi yang cukup selama latihan ditambah dengan olah raga yang teratur. Perlu dilakukan penelitian pada kelompok yang tidak mengikuti latihan di AAL untuk menjadi bahan perbandingan, untuk mengetahui lebih jelas pengaruh latihan fisik dan pasokan gizi yang teratur terhadap pertambahan tinggi badan pada kelompok umur ini.

Dapat disimpulkan bahwa kegiatan fisik yang dilakukan oleh para kadet ini tidak meningkatkan kekuatan genggam, tapi ada perubahan setelah setahun dalam hal ketebalan lemak. Namun, terdapat perbedaan signifikan berupa pertambahan berat badan, meskipun dari sisi ketebalan lemak telah berkurang. Artinya terdapat pertambahan massa tulang dan massa otot. Meskipun demikian, kelompok pertama yang melakukan kegiatan cross-country, tidak mengalami pertambahan badan yang signifikan, meskipun pertambahan tingginya signifikan. Akibatnya, secara umum mereka terlihat lebih kurus dari pada kelompok yang ke dua.

Satu hal penting yang dapat dipelajari dari penelitian ini adalah bahwa ketika makanan berkecukupan tetapi kegiatan fisik sangat banyak dilakukan, pertambahan tinggi badan tidak mengalami gangguan. Hanya saja pertambahan berat badan lebih terganggu oleh karena kebutuhan energi yang ekstra besar. Hal ini penting diketahui oleh masyarakat yang anaknya masih dalam tahap tumbuh kembang, bahwa kegiatan yang banyak, harus diimbangi dengan pasokan makanan yang cukup pula.

\section{Daftar Pustaka}

Arikunto S (1998) Prosedur Penelitian, Suatu Pendekatan Praktek. Jakarta: PT Rineka Cipta.

Anonim (2005) Buku Praktis Ahli Gizi. Malang: Jurusan Politeknik Kesehatan.

Glinka J (1987) Antropologi Ragawi: Handout Untuk Mahasiswa. Surabaya: FISIP Unair (Tidak Diterbitkan).

Hartono A (2000) Asuhan Nutrisi Rumah Sakit: Diagnosis, Konseling, dan Preskripsi. Jakarta: Buku Kedokteran EGC.

Muhilal F, Jalal, \& Hardinsyah (1998) Angka Kecukupan Gizi yang Dianjurkan. Widyakarya Nasional Pangan dan Gizi VI. LIPI, Jakarta.

Mulyono (2002) Keserasian Ukuran Tempat Sujud (Shof Sholat) dengan Antropometri Jama'ah di Masjid se Kodya Surabaya. Surabaya: Laporan Penelitian Universitas Airlangga (Tidak Diterbitkan).

Sajoto M (1995) Peningkatan dan Pembinaan Kekuatan Kondisi Fisik dalam Olah Raga. Semarang: Dahara Prize.

Soetjiningsih (1995) Tumbuh Kembang Anak. Jakarta: Buku Kedokteran EGC

Supariasa I D N, Bakri B, Fajar I (2002) Penilaian Status Gizi. Jakarta: Buku Kedokteran EGC.

Trihendardi C (2005) Step By Step SPSS 13: Analisis Data Statistik. Yogyakarta: Penerbit Andi. 